\title{
Review
}

\section{Molecular aspects of flower senescence and strategies to improve flower longevity}

\author{
Kenichi Shibuya* \\ Institute of Vegetable and Floriculture Science, NARO, 2-1 Fujimoto, Tsukuba, Ibaraki 305-0852, Japan
}

\begin{abstract}
Flower longevity is one of the most important traits for ornamental plants. Ethylene plays a crucial role in flower senescence in some plant species. In several species that show ethylene-dependent flower senescence, genetic modification targeting genes for ethylene biosynthesis or signaling has improved flower longevity. Although little is known about regulatory mechanisms of petal senescence in flowers that show ethyleneindependent senescence, a recent study of Japanese morning glory revealed that a NAC transcription factor, EPHEMERAL1 (EPH1), is a key regulator in ethylene-independent petal senescence. EPH1 is induced in an age-dependent manner irrespective of ethylene signal, and suppression of EPH1 expression dramatically delays petal senescence. In ethylene-dependent petal senescence, comprehensive transcriptome analyses revealed the involvement of transcription factors, a basic helix-loop-helix protein and a homeodomain-leucine zipper protein, in the transcriptional regulation of the ethylene biosynthesis enzymes. This review summarizes molecular aspects of flower senescence and discusses strategies to improve flower longevity by molecular breeding.
\end{abstract}

Key Words: ethylene, flower, programmed cell death, senescence, transcription factor.

\section{Introduction}

Flower longevity is an important trait determining the quality of commercial flowers. Consumers appreciate longlasting flowers and the distribution industry desires reduction of deterioration in the quality of flowers in the distribution chain. Several techniques have been developed to improve flower life for some cut flowers but not for many other flowers. An understanding of physiology and molecular biology of flower senescence is needed to efficiently improve flower longevity.

Flower longevity varies among plant species. For example, flowers of morning glory wilt within one day, whereas flowers of Phalaenopsis stay open several months. Flower longevity is considered to be closely linked with reproductive strategy of flowering plants, as it is an important factor in attracting pollinators (Primack 1985). In some plant species, flower life is terminated by the abscission of flower parts in the presence or absence of petal senescence (van Doorn 2001). Here I use the term 'flower senescence' for phenomena that include both petal senescence and the abscission of flower parts. In this review, I mostly focus on petal senescence. Petal senescence is a type of programmed

Communicated by Takashi Onozaki

Received July 31, 2017. Accepted November 14, 2017.

First Published Online in J-STAGE on February 27, 2018.

*Corresponding author (e-mail: shibuken@affrc.go.jp) cell death (PCD), which is a tightly regulated developmental process (Pennell and Lamb 1997, Rogers 2006, Shibuya et al. 2016, van Doorn and Woltering 2008). Treatment with cycloheximide, which inhibits protein synthesis, delays petal senescence in several plants, supporting that petal senescence is an active process (Shibuya and Ichimura 2016). As petal senescence is a genetically programmed developmental process, molecular breeding as well as classical breeding could improve flower longevity. Several reviews on flower senescence have been published (Rogers 2013, Scariot et al. 2014, Shahri and Tahir 2014, Shibuya and Ichimura 2016, Shibuya et al. 2016, van Doorn and Woltering 2008). In this review, I outline studies on physiology and molecular biology of petal senescence in the context of molecular breeding.

\section{Ethylene response of cut flowers}

Patterns of flower senescence can be classified based on differences in how ethylene is involved: ethylene dependent and ethylene independent. In flowers of plant species showing ethylene-dependent senescence, an autocatalytic rise in endogenous ethylene production triggers petal senescence (Shibuya 2012, Woltering and van Doorn 1988). In general, inhibition of ethylene biosynthesis or perception delay flower senescence, and exogenous ethylene treatment accelerates senescence in these flowers. On the other hand, ethylene seems to have little effect on flower senescence in other plant species (Shibuya 2012, Woltering and van Doorn 
1988). Flowers of species showing ethylene-independent senescence usually produce little ethylene during flower senescence. Treatment with ethylene inhibitors does not improve flower longevity and exogenous ethylene does not accelerate flower senescence. In addition to ethylenedependent and ethylene-independent senescence, there are intermediate or mixed patterns of senescence (Shibuya 2012). For example, flowers of Campanula show ethyleneindependent senescence in the absence of pollination; however, once pollinated, these flowers start producing ethylene, which causes accelerated petal senescence (Kato et al. 2002). In flowers of Mirabilis jalapa (four-o'clock), endogenous ethylene has little effect on petal senescence but application of exogenous ethylene accelerates it $(\mathrm{Xu}$ et al. 2007).

It would be useful to know which particular species of flowers respond to exogenous ethylene, because in many cases, endogenous ethylene is involved in the regulation of flower senescence in species that respond to exogenous ethylene. Responses to ethylene vary greatly among plant species. In carnation, $0.6 \mu \mathrm{L} \mathrm{L}^{-1}$ ethylene induces visible petal senescence symptoms (inward rolling of petals) within $12 \mathrm{~h}$ (Wu et al. 1991), while in chrysanthemum, little effect is observed when flowers are treated with $1 \mu \mathrm{L} \mathrm{L}^{-1}$ ethylene for more than ten days (Doi et al. 2003). Woltering and van Doorn (1988) evaluated ethylene sensitivity in 96 plant species by treating with $3 \mu \mathrm{L} \mathrm{L}^{-1}$ ethylene for 22 to $24 \mathrm{~h}$. In some species, however, longer exposure to ethylene has been reported to result in accelerated flower senescence. For example, daffodil was classified as a flower with very low ethylene sensitivity, but continuous treatment with $1 \mu \mathrm{L} \mathrm{L}^{-1}$ ethylene hastens petal senescence (Hunter et al. 2004). Here, the ethylene response of cut flowers was classified based on the results reported in the literature and on the results of our studies (Kondo et al. 2017, Table 1). It should be noted that responses to ethylene vary even within species, but are specific to cultivars. Table 1 shows the results of tested cultivars in the literature. Furthermore, concentration of ethylene, time of treatment, experimental period, and evaluation of ethylene response vary among experiments. For the experiments reported in the papers or proceedings written in Japanese, I made notes on Table 1.

\section{Genes involved in ethylene biosynthesis}

The ethylene biosynthetic pathway in plants has been characterized, and genes encoding key enzymes have been isolated (Kende 1993, Lin et al. 2009, Yang and Hoffman 1984). Ethylene is synthesized through the following pathway: L-methionine $\rightarrow S$-adenosyl-L-methionine $\rightarrow 1$-aminocyclopropane-1-carboxylic acid (ACC) $\rightarrow$ ethylene. The last two reactions are catalyzed by ACC synthase and ACC oxidase.

ACC synthase (ACS) and ACC oxidase (ACO) are encoded by multigene families, and genes encoding these enzymes have been isolated from many ornamental plant species (Shibuya and Ichimura 2016). ACS genes have been isolated, for example, from carnation (Henskens et al. 1994, Jones and Woodson 1999, Park et al. 1992), geranium (Wang and Arteca 1995), Phalaenopsis (Bui and O'Neill 1998), petunia (Lindstrom et al. 1999), rose (Wang et al. 2004), snapdragon (Woltering et al. 2005), morning glory (Frankowski et al. 2009), tree peony (Zhou et al. 2013), and Oncidium (Shi and Liu 2016). ACO genes have been isolated, for example, from carnation (Tanase et al. 2012, Wang and Woodson 1991), Phalaenopsis (Nadeau et al. 1993), petunia (Tang et al. 1993), geranium (Clark et al. 1997), snapdragon (Woltering et al. 2005), tulip (Momonoi et al. 2007), rose (Xue et al. 2008), tree peony (Zhou et al. 2013), and morning glory (Wilmowicz et al. 2014). ACS and ACO genes are differentially regulated in a spatial and temporalspecific manner. In carnation, for example, of the three ACS genes, DcACS1 is most abundant in petals while DcACS2 and DcACS3 are preferentially expressed in styles (Jones and Woodson 1999). Differential expression of ACO genes has also been reported in petunia (Tang et al. 1994).

The regulatory mechanisms of $A C S$ and $A C O$ genes during flower senescence are still largely unknown. Recently, two transcription factors (TFs), homeodomain-leucine zipper (HD-Zip) and basic helix-loop-helix (bHLH), were reported to regulate these genes. PhHD-Zip, a HD-Zip TF gene, was up-regulated during petal senescence, and suppression of PhHD-Zip by virus-induced gene silencing significantly extended flower longevity in petunia (Chang et al. 2014). Silencing of PhHD-Zip reduced ethylene production and the abundance of transcripts of $A C O 1, A C O 4$ and $A C S$. Furthermore, Yin et al. (2015) showed that PhFBH4, a bHLH TF, regulates petal senescence by modulating the ethylene biosynthesis pathway in petunia. Silencing of PhFBH4 reduced and overexpression increased transcript abundance of $A C S 1$ and $A C O 1$. The authors suggested that ACS1 is a direct target of PhFBH4 since PhFBH4 physically interacts with a cis-element in the ACS1 promoter. Further studies on these TFs will shed light on the transcriptional regulation of the ethylene biosynthesis pathway during petal senescence.

\section{Genes involved in ethylene signal transduction}

Ethylene signaling is mediated by a complex multicomponent pathway (Lin et al. 2009). ETR1 (ETHYLENE RESPONSE1) has been identified as an ethylene receptor (Chang et al. 1993). Five ethylene receptor genes were cloned from Arabidopsis thaliana (Hua et al. 1995, Sakai et al. 1998) and these receptors have been shown to be negative regulators of ethylene responses (Hua and Meyerowitz 1998). The receptors act through CTR1 (CONSTITUTIVE TRIPLE RESPONSE1), which negatively regulates ethylene signaling (Huang et al. 2003, Kieber et al. 1993). Downstream of the receptor-CTR1 complex is EIN2 (ETHYLENE INSENSITIVE2), which positively regulates signaling (Alonso et al. 1999, Qiao et al. 2009, 2012). 
Table 1. Ethylene response of cut flowers

\begin{tabular}{|c|c|c|c|}
\hline Plant species & Cultivar & Ethylene treatment & Reference \\
\hline \multicolumn{4}{|c|}{ Plant species that show accelerated flower senescence by exogenous ethylene treatment } \\
\hline Antirrhinum majus (snapdragon) & Yellow Butterfly & $2,10 u \mathrm{~L} \mathrm{~L}^{-1}, 48 \mathrm{~h}$ & Ichimura et al. (2008) \\
\hline Astilbe & - & $10 \mu \mathrm{L} \mathrm{L}^{-1}$, continuous & Kondo et al. (2017) \\
\hline Bouvardia & Royal Daphne & $10 \mu \mathrm{L} \mathrm{L}^{-1}$, continuous & Kondo et al. (2017) \\
\hline Calendula & - & $10 \mu \mathrm{L} \mathrm{L}^{-1}$, continuous & Kondo et al. (2017) \\
\hline Campanula medium & Champion Pink & $2 \mu \mathrm{L} \mathrm{L}^{-1}, 48 \mathrm{~h}$ & Kato et al. (2002) \\
\hline Cattleya & Pearl Harbor & $0.3,3 \mu \mathrm{L} \mathrm{L}^{-1}$, continuous & Goh et al. (1985) \\
\hline Cymbidium & Angelica & $\begin{array}{l}0.3,3 \mu \mathrm{L} \mathrm{L}^{-1} \text {, continuous } \\
3 \mu \mathrm{L} \mathrm{L}^{-1}, 40 \mathrm{~h}\end{array}$ & Goh et al. (1985) \\
\hline Delphinium hybrid & Bellamosum & $10 \mu \mathrm{L} \mathrm{L}^{-1}, 24 \mathrm{~h}$ & Ichimura et al. (2009) \\
\hline Dendrobium hybrid & Jaquelyn Thomas & $2 \mu \mathrm{L} \mathrm{L}^{-1}$, continuous & Porat et al. (1994) \\
\hline \multirow[t]{2}{*}{ Dianthus caryophyllus (carnation) } & Sandra & $0.6 \mu \mathrm{L} \mathrm{L}^{-1}, 12 \mathrm{~h}$ & Wu et al. (1991) \\
\hline & Chinera & & \\
\hline Eustoma grandiflorum & $\begin{array}{l}\text { White Sim } \\
\text { Azuma-no-sakura } \\
\text { Azuma-no-murasaki } \\
\text { Maite Sky } \\
\text { New Small Lady } \\
\text { Asuka-no-sazanami }\end{array}$ & $10 \mu \mathrm{L} \mathrm{L}^{-1}, 24 \mathrm{~h}$ & Shimizu-Yumoto and Ichimura (2009) \\
\hline Gentiana scabra & Shinbisei & $0.5,2,5,10 \mu \mathrm{L} \mathrm{L}^{-1}, 24 \mathrm{~h}$ & Shimizu-Yumoto and Ichimura (2012) \\
\hline Lathyrus odoratus (sweet pea) & Miranda & $0.2,2 \mu \mathrm{L} \mathrm{L}^{-1}, 24 \mathrm{~h}$ & Shimizu-Yumoto and Ichimura (2006) \\
\hline \multirow[t]{4}{*}{ Lilium (lily, Asiatic hybrid) } & Cordelia & $100 \mu \mathrm{L} \mathrm{L}^{-1}, 24 \mathrm{~h}$ & Elgar et al. (1999) \\
\hline & Apeldoorn & & \\
\hline & Goldena & & \\
\hline & Mona & & \\
\hline Matthiola incana (stock) & - & $1 \mu \mathrm{L} \mathrm{L}^{-1}, 48 \mathrm{~h}$ & Celikel and Reid (2002) \\
\hline Narcissus pseudonarcissus (daffodil) & Dutch Master & $1 \mu \mathrm{L} \mathrm{L}^{-1}$, continuous & Hunter et al. (2004) \\
\hline Oxypetalum caeruleum (blue star) & - & $2,10 \mu \mathrm{L} \mathrm{L}^{-1}, 24 \mathrm{~h}$ & Hiraya et al. (2002) \\
\hline Paphiopedilum & Grand Canyon $\times$ Sparsholt & $3 \mu \mathrm{L} \mathrm{L}^{-1}$, continuous & Goh et al. (1985) \\
\hline Rosa hybrida (rose) & $\begin{array}{l}\text { Sonia } \\
\text { Delilah }\end{array}$ & $1 \mu \mathrm{L} \mathrm{L}^{-1}, 48 \mathrm{~h}$ & Ichimura et al. (2005) \\
\hline Spiraea cantoniensis & - & $10 \mu \mathrm{L} \mathrm{L}^{-1}$, continuous & Kondo et al. (2017) \\
\hline Spiraea thunbergii & - & $10 \mu \mathrm{L} \mathrm{L}^{-1}$, continuous & Kondo et al. (2017) \\
\hline Strelitzia reginae & - & $10 \mu \mathrm{L} \mathrm{L}^{-1}$, continuous & Kondo et al. (2017) \\
\hline Trachymene coerulea (Didiscus caeruleus) & - & $10 \mu \mathrm{L} \mathrm{L}^{-1}$, continuous & Kondo et al. (2017) \\
\hline Vanda & Miss Joaquim & $\begin{array}{l}0.3,3 \mu \mathrm{L} \mathrm{L}^{-1} \text {, continuous } \\
3 \mu \mathrm{L} \mathrm{L}^{-1}, 20 \mathrm{~h}\end{array}$ & Goh et al. (1985) \\
\hline Zantedeschia (calla) & $\begin{array}{l}\text { Wedding March } \\
\text { Captain Romance }\end{array}$ & $10 \mu \mathrm{L} \mathrm{L}^{-1}$, continuous & Kondo et al. (2017) \\
\hline \multicolumn{4}{|c|}{ Plant species that do not show accelerated flower senescence by exogenous ethylene treatment } \\
\hline Ammi majus & - & $10 \mu \mathrm{L} \mathrm{L}^{-1}$, continuous & Kondo et al. (2017) \\
\hline Bupleurum rotundifolium & - & $10 \mu \mathrm{L} \mathrm{L}^{-1}$, continuous & Kondo et al. (2017) \\
\hline \multirow[t]{2}{*}{ Celosia } & Sakata Pride & $10 \mu \mathrm{L} \mathrm{L}^{-1}$, continuous & Kondo et al. (2017) \\
\hline & Castle Pink & & \\
\hline \multirow[t]{6}{*}{ Dendranthema grandiflora (chrysanthemum) } & Iwa-no-hakusen & $1 \mu \mathrm{L} \mathrm{L}^{-1}$, continuous & Doi et al. (2003) \\
\hline & Seiun & & \\
\hline & Jinba & & \\
\hline & Seiko-ougon & & \\
\hline & Toku-meimon & & \\
\hline & Kin-meimon & & \\
\hline Dendrobium & Jaquelyn Hawaii & $\begin{array}{l}0.3,3 \mu \mathrm{L} \mathrm{L}^{-1}, \text { continuous } \\
3 \mu \mathrm{L} \mathrm{L}^{-1} 20 \mathrm{~h}\end{array}$ & Goh et al. (1985) \\
\hline & - & $1 \mu \mathrm{L} \mathrm{L}^{-1}$, continuous & Serek et al. (1994) \\
\hline \multirow{2}{*}{$\begin{array}{l}\text { Lilium (lily, Oriental hybrid) } \\
\text { Liliolus sp. }\end{array}$} & Cassandra & $100 \mu \mathrm{L} \mathrm{L}^{-1}, 24 \mathrm{~h}$ & Elgar et al. (1999) \\
\hline & Stargazer & & \\
\hline \multirow[t]{2}{*}{ Lilium longiflorum (lily) } & Gelria & $100 \mu \mathrm{L} \mathrm{L}^{-1}, 24 \mathrm{~h}$ & Elgar et al. (1999) \\
\hline & Princess Gracia & & \\
\hline \multirow[t]{2}{*}{ Oncidium } & Carnival Costume & $0.3,3 \mu \mathrm{L} \mathrm{L}^{-1}$, continuous & Goh et al. (1985) \\
\hline & Summer Sprite & & \\
\hline Tulipa hybrida (tulip) & Golden Apeldoorn & 3-5 $\mu \mathrm{L} \mathrm{L}^{-1}$, continuous & Sexton et al. (2000) \\
\hline Tulipa kaufmanniana (tulip) & Shakespeare & $3-5 \mu \mathrm{L} \mathrm{L}^{-1}$, continuous & Sexton et al. $(2000)$ \\
\hline
\end{tabular}

Concentration of ethylene, time of treatment, and experimental period varied among experiments (for details, see references). For plant species examined by Kondo et al. (2017), treatment was with $10 \mu \mathrm{L} \mathrm{L}^{-1}$ ethylene continuously at $23^{\circ} \mathrm{C}$ and response to ethylene (petal wilting and/or the abscission of flower parts) was evaluated every $24 \mathrm{~h}$ for 3 days. For Eustoma grandiflorum and Lathyrus odoratus examined by Shimizu-Yumoto and Ichimura $(2006,2009)$, ethylene was treated for $24 \mathrm{~h}$ and then kept in ethylene-free air at $23^{\circ} \mathrm{C}$. Response to ethylene was evaluated based on the time from the end of the ethylene treatment to the time when petals wilt as described in Shimizu-Yumoto and Ichimura (2012). -, no cultivar name or unknown. 
Toward the end of the signaling pathway, ethylene responses are mediated by TFs including EIN3 (ETHYLENE INSENSITIVE3) and ERF1 (ETHYLENE RESPONSE FACTOR1) (Chao et al. 1997, Solano et al. 1998).

Genes encoding ethylene receptors have been isolated from several ornamental plant species; for example, rose (Müller et al. 2000), geranium (Dervinis et al. 2000), carnation (Shibuya et al. 2002), Delphinium (Kuroda et al. 2003, Tanase and Ichimura 2006), chrysanthemum (Narumi et al. 2005), gladiolus (Arora et al. 2006), petunia (Wang and Kumar 2007), Oncidium (Huang et al. 2007b), and tree peony (Zhou et al. 2010). Genes have been reported that encode CTR1 in rose (Müller et al. 2002) and Delphinium (Kuroda et al. 2004), EIN2 in petunia (Shibuya et al. 2004) and carnation (Fu et al. 2011), and EIN3 in carnation (Iordachescu and Verlinden 2005, Waki et al. 2001), rose (Müller et al. 2003), petunia (Shibuya and Clark 2006), and tree peony (Zhou et al. 2010). In addition to components involved in an ethylene signal cascade, a MADS-box TF, FOREVER YOUNG FLOWER (FYF), acts as a repressor of flower senescence by repressing ethylene responses in Arabidopsis (Chen et al. 2011, 2015). The ectopic expression of Arabidopsis FYF causes both delayed senescence and delayed abscission of the floral organs in Arabidopsis (Chen et al. 2011). Recently, FYF was reported to negatively regulate ethylene response DNA-binding factors by activating an ethylene-responsive factor in the regulation of floral organ senescence and abscission (Chen et al. 2015).

Transgenic approaches to improve flower longevity by manipulating ethylene biosynthesis and responses

Since genes involved in ethylene biosynthesis and signal transduction have been isolated from several ornamental plants, flower longevity can be improved by transgenic techniques targeting those genes. In the 1990s, Savin et al. (1995) produced transgenic carnation suppressing $A C O$ expression by an anti-sense method. In the transgenic carnation, ethylene production was reduced and petal senescence was clearly delayed. The vase life of untransformed carnation flowers was about 5 days from day of harvest to petal wilting, while flowers of transgenic plants had a vase life of 8 to 9 days at $21^{\circ} \mathrm{C}$. After this report, transgenic plants with reduced $A C S$ or $A C O$ expression were shown to have prolonged flower longevity in petunia (Huang et al. 2007a) and torenia (Aida et al. 1998, Table 2). As with chemical approaches, inhibition of ethylene perception is a more efficient way to prolong flower life. The introduction of a mutated ethylene receptor gene, such as Arabidopsis etr1-1, is a particularly desirable strategy because even a single genetic manipulation may confer ethylene insensitivity in a variety of heterologous plant species (Wilkinson et al. 1997). This strategy has been applied to several ornamental crops, including Campanula (Sriskandarajah et al. 2007), carnation (Bovy et al. 1999), Kalanchoe (Sanikhani et al. 2008), Nemesia (Cui et al. 2004), petunia (Wilkinson et al.
1997), and torenia (Tanase et al. 2011), prolonging flower longevity (Table 2). For example, the longevity of nonpollinated flowers in wild-type petunia is 6.7 days on average, while flowers of transgenic plants harboring etr $1-1$ last 16.6 days on plants grown at day/night temperatures of $26 / 21^{\circ} \mathrm{C}$ (Gubrium et al. 2000). In addition to ethylene receptors, suppression of ethylene signaling components such as EIN2 and EIN3 has prolonged flower life in petunia (Shibuya et al. 2004, Shibuya and Clark 2006, Table 2). Besides ethylene biosynthetic enzymes and signaling components, the ectopic expression of Arabidopsis FYF has been reported to delay petal senescence by repressing ethylene responses in Eustoma grandiflorum (Chen et al. 2011). Suppression of PhHD-Zip and PhFBH4 also results in delayed petal senescence in petunia (Chang et al. 2014, Yin et al. 2015, Table 2). The longevity of nonpollinated wild-type flowers is about 7 days, while suppression of $P h F B H 4$ by expressing the antisense $P h F B H 4$ fragment extends flower longevity to about 9 days at day/night temperatures of $25 / 20^{\circ} \mathrm{C}$ (Yin et al. 2015).

It should be noted that in transgenic plants with reduced ethylene sensitivity, physiological side effects may limit their commercial use. For example, ethylene-insensitive transgenic petunia exhibits inhibited adventitious root formation and a high percentage of premature death (Clark et al. 1999, Shibuya et al. 2004). These negative side effects are likely due to constitutive ethylene insensitivity in transgenic plants, and the key to circumventing these undesirable side effects is to use a tissue-specific promoter. FLORAL BINDING PROTEIN1 (FBPI) is a floral organ identity gene of petunia that is expressed exclusively in petals and stamens (Angenent et al. 1992). The FBP1 promoter has been used to control the expression of the etrl-1 gene in transgenic carnation (Bovy et al. 1999), Campanula (Sriskandarajah et al. 2007), and Kalanchoe (Sanikhani et al. 2008) with limited side effects (Table 2). Rescently, the InMYB1 promoter from Japanese morning glory was reported to function as a petal-specific promoter in a wide range of dicots including Eustoma, chrysanthemum, carnation, Japanese gentian and stock (Azuma et al. 2016). This promoter could also be used for the improvement of flower longevity similarly to the FBP1 promoter.

\section{Roles of NAC TFs in the regulation of ethylene-} independent petal senescence

In some plant species including lily, tulip, chrysanthemum, iris, and gladiolus, ethylene has little effect on the regulation of petal senescence (Woltering and van Doorn 1988, Table 1). Exogenous ethylene treatment does not accelerate petal senescence, and chemical inhibition of ethylene biosynthesis or perception does not delay senescence in these flowers. Thus, in these flowers, petal senescence has been considered to be regulated through an ethylene-independent pathway. Studies to identify genes that regulate PCD during petal senescence using differential screening and microarray 
Table 2. Examples of transgenic ornamental plants with prolonged flower longevity

\begin{tabular}{|c|c|c|c|}
\hline Plant species & Gene construct & Expression & Reference \\
\hline \multicolumn{4}{|l|}{ Suppression of ethylene biosynthesis } \\
\hline Carnation (Dianthus caryophyllus) & ACO (D. caryophyllus) & Silencing (Antisense) & Savin et al. (1995) \\
\hline 'Scania' and 'White Sim' & MAC promoter & & \\
\hline Carnation (Dianthus caryophyllus) & ACO (D. caryophyllus) & Silencing (Sense) & Kosugi et al. (2000) \\
\hline 'Nora' & CaMV 35S promoter & & \\
\hline Carnation (Dianthus caryophyllus) & ACS (D. caryophyllus) & Silencing (Sense) & Iwazaki et al. (2004) \\
\hline 'Nora' & CaMV 35S promoter & & \\
\hline Petunia (Petunia hybrida Hort. Vilm.-Andr.) & ACS/ACO (Brassica oleracea $)$ & Silencing (Antisense) & Huang et al. (2007a) \\
\hline $\begin{array}{l}\text { Torenia (Torenia fournieri) } \\
\text { 'Crown Mix', 'Crown Blue', and 'White' }\end{array}$ & $\begin{array}{l}\text { CaMV 35S promoter } \\
\text { ACO }(\text { T. fournieri }) \\
\text { CaMV 35S promoter }\end{array}$ & Silencing (Sense, Antisense) & Aida et al. (1998) \\
\hline \multicolumn{4}{|l|}{ Suppression of ethylene signaling } \\
\hline Campanula (Campanula carpatica) & etr1-1 (A. thaliana) & Ectopic & Sriskandarajah et al. (2007) \\
\hline 'Blue Uniform' & Petunia $F B P 1$ promoter & & \\
\hline Carnation (Dianthus caryophyllus) & etr1-1 (A. thaliana) & Ectopic & Bovy et al. (1999) \\
\hline 'Lena' & CaMV 35 S/Petunia $F B P 1$ promoter & & \\
\hline Kalanchoe (Kalanchoe blossfeldiana) & etr1-1 (A. thaliana) & Ectopic & Sanikhani et al. (2008) \\
\hline 'Debbie' & Petunia $F B P 1$ promoter & & \\
\hline Nemesia (Nemesia strumosa) & Cm-ETR1/H69A (Cucumis melo) & Ectopic & Cui et al. (2004) \\
\hline genotype White & CaMV 35S promoter & & \\
\hline Petunia (Petunia hybrida) & etr1-1 (A. thaliana) & Ectopic & Wilkinson et al. (1997) \\
\hline 'Mitchell Diploid' & CaMV $35 \mathrm{~S}$ promoter & & \\
\hline \multirow{2}{*}{ Petunia (Petunia hybrida Hort. Vilm.-Andr.) } & boers $($ B. oleracea $)$ & Ectopic & Shaw et al. (2002) \\
\hline & CaMV 35S promoter & & \\
\hline Petunia (Petunia hybrida) & EIN2 (P. hybrida) & Silencing (Sense, RNAi) & Shibuya et al. (2004) \\
\hline 'Mitchell Diploid' & CaMV 35S promoter & & \\
\hline Petunia (Petunia hybrida) & EIL2 (P. hybrida) & Silencing (Sense) & Shibuya and Clark (2006) \\
\hline 'Mitchell Diploid' & CaMV 35S promoter & & \\
\hline Torenia (Torenia fournieri) & Dc-ETRInr (D. caryophyllus) & Ectopic & Tanase et al. (2011) \\
\hline 'Crown Mix' & CaMV 35S promoter & & \\
\hline \multicolumn{4}{|l|}{ Altered expression of transcription factors } \\
\hline \multirow[t]{2}{*}{ Eustoma (Eustoma grandiflorum) } & $F Y F($ A. thaliana $)$ & Ectopic & Chen et al. (2011) \\
\hline & CaMV 35S promoter & & \\
\hline Japanese morning glory (Ipomoea nil) & EPH1 (I. nil) & Silencing (RNAi) & Shibuya et al. (2014) \\
\hline 'Violet' & CaMV 35S promoter & & \\
\hline Petunia (Petunia hybrida) & PhHD-Zi (P. hybrida) & Silencing (VIGS) & Chang et al. (2014) \\
\hline 'Primetime Blue' & & & \\
\hline Petunia (Petunia hybrida) & PhFBH4 (P. hybrida) & Silencing (VIGS, antisense) & Yin et al. (2015) \\
\hline 'Primetime Blue' and 'Mitchell Diploid' & & & \\
\hline
\end{tabular}

analysis have identified upregulation or downregulation of numerous genes in several plant species, including Hemerocallis (Panavas et al. 1999) and Iris (van Doorn et al. 2003). However, no genes specific for cell death have yet been identified (van Doorn and Woltering 2008). The lack of effective transformation methods makes it difficult to determine the function of isolated genes in these plant species.

Petal senescence of Japanese morning glory 'Violet' is considered to be regulated independently of endogenous ethylene because chemical inhibition of ethylene biosynthesis or perception does not delay petal senescence (Shibuya 2012, Shinozaki et al. 2011, Yamada et al. 2006). Recently, EPHEMERAL1 (EPH1), a NAC (NAM/ATAF1,2/CUC2) $\mathrm{TF}$, was shown to regulate petal senescence in 'Violet'. EPH1 is expressed almost specifically in senescing petals but negligibly in vegetative tissues. Transgenic plants with suppressed $E P H 1$ expression showed a great delay in petal senescence (Fig. 1, Shibuya et al. 2014). The transgenic plants grew normally and did not show negative side effects during cultivation in a growth chamber. The constitutive CaMV 35S promoter was used to express the EPH1 RNAi construct, but the expression patterns of the native EPHI gene with quite specific expression in petals would likely result in negligible side effects.

The rise in abundance of EPH1 transcripts was not suppressed in petals treated with 1-methylcyclopropene, a specific inhibitor of ethylene action, or in petals of transgenic plants with reduced ethylene sensitivity due to suppression of EIN2 expression. This suggests that the expression of $E P H 1$ is regulated independently of an endogenous ethylene signal. In the transgenic plants with suppressed EPH1 expression, expression of several PCD-related gene homologs, 
Time after opening $(\mathrm{h})$

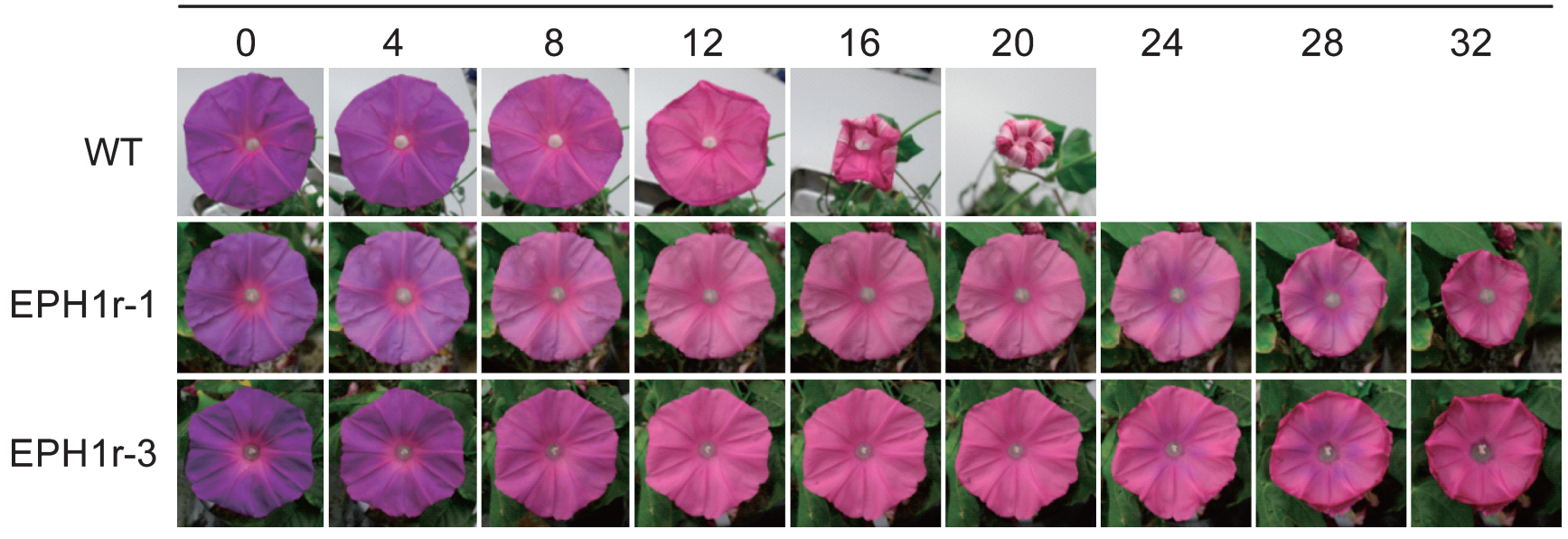

Fig. 1. Time course of visible petal senescence in wild-type (WT) and transgenic plant lines with suppressed EPH1 expression (EPH1r-1 and EPH1r-3). The transgenic plants show approximately doubled flower longevity (Shibuya et al. 2014).

including vacuolar processing enzyme and autophagyrelated genes, were suppressed. In ethylene-independent petal senescence, a NAC TF such as EPH1 may be induced developmentally in an age-dependent manner irrespective of ethylene signal and upregulate PCD-related genes, resulting in petal senescence. In tulip, which shows ethyleneindependent petal senescence, comparative analysis of gene expression revealed that several NAC TFs are upregulated in senescing inner tepals (Shibuya, unpublished). It is of particular interest whether NAC TFs play a similar role in other ethylene-independent species.

NAC TFs may also be involved in the regulation of ethylene-dependent petal senescence. The upregulation of NAC TFs in senescing petals has been reported in plants that show ethylene-dependent senescence, including Arabidopsis (Wagstaff et al. 2009), wallflower (Price et al. 2008), and petunia (Broderick et al. 2014). In petunia, expression of multiple NAC TF genes was downregulated in ethylene-insensitive petals in which expression of etr $1-1$ was induced (Wang et al. 2013), suggesting that these NAC TF genes are regulated through an ethylene signal. In ethylenedependent petal senescence, endogenous ethylene induced by pollination or stress may hasten the timing of upregulation of a NAC TF gene, resulting in accelerated petal senescence.

\section{Conclusion and future perspective}

The role of ethylene in petal senescence has been well characterized. Technically, it is possible to produce long-lasting flowers in plant species that show ethylene-dependent senescence by manipulating genes involved in ethylene biosynthesis or signaling. The introduction of a mutated ethylene receptor gene such as Arabidopsis etrl-1 under the control of a petal-specific promoter would be the most effective way to improve flower longevity in these plants. In contrast, regulatory mechanisms of ethylene-independent petal senescence have been unclear. Recently, a NAC TF, $\mathrm{EPH} 1$, has been shown as a key regulator of ethyleneindependent petal senescence through studies of Japanese morning glory. Since NAC TFs are also upregulated in senescing petals of ethylene-dependent species, NAC TFs may be a master regulator of PCD that integrates age-dependent (ethylene-independent) and ethylene-dependent signals. More studies are necessary to determine whether NAC TFs commonly regulate petal senescence in both ethyleneindependent and ethylene-dependent species.

Molecular breeding of ornamental plants has entered a new era by the emergence of efficient genome editing systems such as CRISPR/Cas9. Although transgenic ornamental plants with prolonged flower longevity have been produced since the 1990s, there has been a lack of commercialization. A barrier could be the cost and public acceptance of genetically modified plants. Genome-editing techniques may change such a situation, because it is possible to make knockout mutants for targeted genes that do not harbor transgenes. This technique would be particularly efficient for a gene that plays a role only in a specific phenomenon, because knockout of the gene would not cause undesirable side effects. Information on genome sequences is accumulating in ornamental plant species including carnation (Yagi et al. 2014), orchid (Cai et al. 2015), petunia (Bombarely et al. 2016), Japanese morning glory (Hoshino et al. 2016), and sunflower (Badouin et al. 2017). Future work will reveal new gene targets of molecular breeding for improving flower longevity.

\section{Literature Cited}

Aida, R., T. Yoshida, K. Ichimura, R. Goto and M. Shibata (1998) Extension of flower longevity in transgenic torenia plants incorporating ACC oxidase transgene. Plant Sci. 138: 91-101. 
Alonso, J.M., T.Hirayama, G. Roman, S. Nourizadeh and J.R.Ecker (1999) EIN2, a bifunctional transducer of ethylene and stress responses in Arabidopsis. Science 284: 2148-2152.

Angenent, G.C., M. Busscher, J.Franken, J.N. Mol and A.J.van Tunen (1992) Differential expression of two MADS box genes in wildtype and mutant petunia flowers. Plant Cell 4: 983-993.

Arora, A., S. Watanabe, B. Ma, K. Takada and H. Ezura (2006) A novel ethylene receptor homolog gene isolated from ethylene-insensitive flowers of gladiolus (Gladiolus grandiflora hort.). Biochem. Biophys. Res. Commun. 351: 739-744.

Azuma, M., R. Morimoto, M.Hirose, Y.Morita, A.Hoshino, S. Iida, Y. Oshima, N. Mitsuda, M. Ohme-Takagi and K. Shiratake (2016) A petal-specific InMYB1 promoter from Japanese morning glory: a useful tool for molecular breeding of floricultural crops. Plant Biotechnol. J. 14: 354-363.

Badouin, H., J.Gouzy, C.J.Grassa, F. Murat, S.E. Staton, L. Cottret, C.Lelandais-Briere, G.L.Owens, S.Carrere, B. Mayjonade et al. (2017) The sunflower genome provides insights into oil metabolism, flowering and Asterid evolution. Nature 546: 148-152.

Bombarely,A., M. Moser, A.Amrad, M. Bao, L.Bapaume, C.S. Barry, M.Bliek, M.R.Boersma, L.Borghi, R.Bruggmann et al. (2016) Insight into the evolution of the Solanaceae from the parental genomes of Petunia hybrida. Nat. Plants 2: 16074.

Bovy,A.G., G.C.Angenent, H.J.M. Dons and A.C. van Altvorst (1999) Heterologous expression of the Arabidopsis etr1-1 allele inhibits the senescence of carnation flowers. Mol. Breed. 5: 301-308.

Broderick, S.R., S. Wijeratne, A.J. Wijeratn, L.J. Chapin, T. Meulia and M.L.Jones (2014) RNA-sequencing reveals early, dynamic transcriptome changes in the corollas of pollinated petunias. BMC Plant Biol. 14: 307.

Bui,A.Q. and S.D. O'Neill (1998) Three 1-aminocyclopropane-1carboxylate synthase genes regulated by primary and secondary pollination signals in orchid flowers. Plant Physiol. 116: 419-428.

Cai, J., X.Liu, K. Vanneste, S.Proost, W.C.Tsai, K.W.Liu, L.J.Chen, Y.He, Q.Xu, C.Bian et al. (2015) The genome sequence of the orchid Phalaenopsis equestris. Nat. Genet. 47: 65-72.

Celikel,F.G. and M.S.Reid (2002) Postharvest handling of stock (Matthiola incana). Hortscience 37: 144-147.

Chang, C., S.F.Kwok, A.B.Bleecker and E.M.Meyerowitz (1993) Arabidopsis ethylene-response gene ETR1: similarity of product to two-component regulators. Science 262: 539-544.

Chang, X.X., L. Donnelly, D.Y.Sun, J.P. Rao, M.S. Reid and C.Z. Jiang (2014) A petunia homeodomain-leucine zipper protein, PhHD-Zip, plays an important role in flower senescence. PLoS ONE 9: e88320.

Chao, Q., M. Rothenberg, R. Solano, G. Roman, W. Terzaghi and J.R. Ecker (1997) Activation of the ethylene gas response pathway in Arabidopsis by the nuclear protein ETHYLENE-INSENSITIVE3 and related proteins. Cell 89: 1133-1144.

Chen, M.K., W.H.Hsu, P.F.Lee, M.Thiruvengadam, H.I.Chen and C.H.Yang (2011) The MADS box gene, FOREVER YOUNG $F L O W E R$, acts as a repressor controlling floral organ senescence and abscission in Arabidopsis. Plant J. 68: 168-185.

Chen,W.H., P.F.Li, M.K.Chen, Y.I.Lee and C.H.Yang (2015) FOREVER YOUNG FLOWER negatively regulates ethylene response DNA-binding factors by activating an ethylene-responsive factor to control Arabidopsis floral organ senescence and abscission. Plant Physiol. 168: 1666-1683.

Clark, D.G., C.Richards, Z.Hilioti, S.Lind-Iversen and K. Brown (1997) Effect of pollination on accumulation of ACC synthase and ACC oxidase transcripts, ethylene production and flower petal ab- scission in geranium (Pelargonium $\times$ hortorum L.H. Bailey). Plant Mol. Biol. 34: 855-865.

Clark, D.G., E.K. Gubrium, J.E. Barrett, T.A. Nell and H.J. Klee (1999) Root formation in ethylene-insensitive plants. Plant Physiol. 121: 53-60.

Cui, M.L., K. Takada, B. Ma and H. Ezura (2004) Overexpression of a mutated melon ethylene receptor gene $C m-E T R 1 / H 69 A$ confers reduced ethylene sensitivity in a heterologous plant, Nemesia strumosa. Plant Sci. 167: 253-258.

Dervinis, C., D.G.Clark, J.E. Barrett and T.A. Nell (2000) Effect of pollination and exogenous ethylene on accumulation of ETRI homologue transcripts during flower petal abscission in geranium (Pelargonium $\times$ hortorum L.H. Bailey). Plant Mol. Biol. 42: 847856.

Doi, M., Y. Nakagawa, S. Watabe, K.Aoe, K. Inamoto and H. Imanishi (2003) Ethylene-induced leaf yellowing in cut chrysanthemums (Dendranthema grandiflora Kitamura). J. Japan. Soc. Hort. Sci. 72: 533-535.

Elgar,H.J., A.B. Woolf and R.L.Bieleski (1999) Ethylene production by three lily species and their response to ethylene exposure. Postharvest Biol. Technol. 16: 257-267.

Frankowski, K., J.Kesy, W. Wojciechowski and J. Kopcewicz (2009) Light- and IAA-regulated ACC synthase gene (PnACS) from Pharbitis nil and its possible role in IAA-mediated flower inhibition. J. Plant Physiol. 166: 192-202.

Fu, Z.D., H.N. Wang, J. Liu, J.X. Liu, J. Wang, Z.Q.Zhang and Y.X. Yu (2011) Cloning and characterization of a DCEIN2 gene responsive to ethylene and sucrose in cut flower carnation. Plant Cell Tissue Organ Cult. 105: 447-455.

Goh, C.J., A.H.Halevy, R. Engel and A.M.Kofranek (1985) Ethylene evolution and sensitivity in cut orchid flowers. Sci. Hortic. 26: 5767.

Gubrium,E.K., D.J.Clevenger, D.G.Clark, J.E. Barrett and T.A. Nell (2000) Reproduction and horticultural performance of transgenic ethylene-insensitive petunias. J. Am. Soc. Hortic. Sci. 125: 277281.

Henskens, J.A., G.J. Rouwendal, A. ten Have and E.J. Woltering (1994) Molecular cloning of two different ACC synthase PCR fragments in carnation flowers and organ-specific expression of the corresponding genes. Plant Mol. Biol. 26: 453-458.

Hiraya, T., H. Shimizu and K. Ichimura (2002) Role of ethylene in senescence of cut Oxypetalum florets. J. Japan. Soc. Hort. Sci. 71: $59-61$.

Hoshino,A., V. Jayakumar, E. Nitasaka, A. Toyoda, H. Noguchi, T. Itoh, T. Shin-I, Y. Minakuchi, Y. Koda, A.J. Nagano et al. (2016) Genome sequence and analysis of the Japanese morning glory Ipomoea nil. Nat. Commun. 7: 13295.

Hua, J., C. Chang, Q. Sun and E.M. Meyerowitz (1995) Ethylene insensitivity conferred by Arabidopsis ERS gene. Science 269: 17121714.

Hua, J. and E.M. Meyerowitz (1998) Ethylene responses are negatively regulated by a receptor gene family in Arabidopsis thaliana. Cell 94: 261-271.

Huang, L.C., U.L.Lai, S.F. Yang, M.J.Chu, C.I.Kuo, M.F.Tsai and C.W.Sun (2007a) Delayed flower senescence of Petunia hybrida plants transformed with antisense broccoli ACC synthase and ACC oxidase genes. Postharvest Biol. Technol. 46: 47-53.

Huang, W.F., P.L. Huang and Y.Y.Do (2007b) Ethylene receptor transcript accumulation patterns during flower senescence in Oncidium 'Gower Ramsey' as affected by exogenous ethylene and pollinia cap dislodgment. Postharvest Biol. Technol. 44: 87-94. 
Huang, Y., H. Li, C.E. Hutchison, J.Laskey and J.J.Kieber (2003) Biochemical and functional analysis of CTR1, a protein kinase that negatively regulates ethylene signaling in Arabidopsis. Plant J. 33: 221-233

Hunter, D.A., M.F.Yi, X.J.Xu and M.S. Reid (2004) Role of ethylene in perianth senescence of daffodil (Narcissus pseudonarcissus L. 'Dutch Master'). Postharvest Biol. Technol. 32: 269-280.

Ichimura, K., M. Kishimoto, R. Norikoshi, Y. Kawabata and K. Yamada (2005) Soluble carbohydrates and variation in vase-life of cut rose cultivars 'Delilah' and 'Sonia'. J. Hortic. Sci. Biotechnol. 80: 280 286.

Ichimura, K., S. Yoshioka and H. Yumoto-Shimizu (2008) Effects of silver thiosulfate complex (STS), sucrose and combined pulse treatments on the vase life of cut snapdragon flowers. Environ. Cont. Biol. 46: 155-162.

Ichimura, K., H. Shimizu-Yumoto and R. Goto (2009) Ethylene production by gynoecium and receptacle is associated with sepal abscission in cut Delphinium flowers. Postharvest Biol. Technol. 52 267-272.

Iordachescu, M. and S. Verlinden (2005) Transcriptional regulation of three EIN3-like genes of carnation (Dianthus caryophyllus L. cv. Improved White Sim) during flower development and upon wounding, pollination, and ethylene exposure. J. Exp. Bot. 56: 2011-2018.

Iwazaki, Y., Y. Kosugi, K. Waki, T. Yoshioka and S. Satoh (2004) Generation and ethylene production of transgenic carnations harboring ACC synthase cDNA in sense or antisense orientation. J. Appl. Hort. 6: 67-71.

Jones, M.L. and W.R. Woodson (1999) Differential expression of three members of the 1-aminocyclopropane-1-carboxylate synthase gene family in carnation. Plant Physiol. 119: 755-764.

Kato, M., H. Shimizu, T. Onozaki, N. Tanikawa, H. Ikeda, T. Hisamatsu and K. Ichimura (2002) Role of ethylene in senescence of pollinated and unpollinated Campanula medium flowers. J. Japan. Soc. Hort. Sci. 71: 385-387.

Kende,H. (1993) Ethylene biosynthesis. Annu. Rev. Plant Physiol. Plant Mol. Biol. 44: 283-307.

Kieber, J.J., M. Rothenberg, G. Roman, K.A. Feldmann and J.R. Ecker (1993) CTR1, a negative regulator of the ethylene response pathway in Arabidopsis, encodes a member of the raf family of protein kinases. Cell 72: 427-441.

Kondo, M., K. Shibuya and K. Ichimura (2017) Sensitivity to ethylene and availability of preservative on the vase life of 15 important cut flowers. Hort. Res. (Japan) 16 (Suppl. 1): 438.

Kosugi,Y., K. Shibuya, N.Tsuruno, Y. Iwazaki, A. Mochizuki, T. Yoshioka, T. Hashiba and S. Satoh (2000) Expression of genes responsible for ethylene production and wilting are differently regulated in carnation (Dianthus caryophyllus L.) petals. Plant Sci. 158: 139-145.

Kuroda, S., M. Hakata, Y. Hirose, M. Shiraishi and S. Abe (2003) Ethylene production and enhanced transcription of an ethylene receptor gene, ERS1, in Delphinium during abscission of florets. Plant Physiol. Biochem. 41: 812-820.

Kuroda, S., Y.Hirose, M. Shiraishi, E. Davies and S.Abe (2004) Coexpression of an ethylene receptor gene, ERS1, and ethylene signaling regulator gene, CTR1, in Delphinium during abscission of florets. Plant Physiol. Biochem. 42: 745-751.

Lin,Z., S.Zhong and D. Grierson (2009) Recent advances in ethylene research. J. Exp. Bot. 60: 3311-3336.

Lindstrom, J.T., C.H. Lei, M.L. Jones and W.R. Woodson (1999) Accumulation of 1-aminocyclopropane-1-carboxylic acid (ACC) in petunia pollen is associated with expression of a pollen-specific ACC synthase late in development. J. Am. Soc. Hortic. Sci. 124: $145-151$.

Momonoi, K., K. Shoji and K. Yoshida (2007) Cloning and characterization of ACC oxidase genes from tulip. Plant. Biotechnol. 24: 241-246.

Müller, R., B.M. Stummann and M. Serek (2000) Characterization of an ethylene receptor family with differential expression in rose (Rosa hybrida L.) flowers. Plant Cell Rep. 19: 1232-1239.

Müller, R., C.A.Owen, Z.T.Xue, M.Welander and B.M.Stummann (2002) Characterization of two CTR-like protein kinases in Rosa hybrida and their expression during flower senescence and in response to ethylene. J. Exp. Bot. 53: 1223-1225.

Müller, R., C.A. Owen, Z.T.Xue, M.Welander and B.Stummann (2003) The transcription factor EIN3 is constitutively expressed in miniature roses with differences in postharvest life. J. Hortic. Sci. Biotechnol. 78: 10-14.

Nadeau, J.A., X.S.Zhang, H. Nair and S.D. Oneill (1993) Temporal and spatial regulation of 1-aminocyclopropane-1-carboxylate oxidase in the pollination-induced senescence of orchid flowers. Plant Physiol. 103: 31-39.

Narumi,T., Y.Kanno, M.Suzuki, S.Kishimoto, A.Ohmiya and S. Satoh (2005) Cloning of a cDNA encoding an ethylene receptor (DG-ERS1) from chrysanthemum and comparison of its mRNA level in ethylene-sensitive and -insensitive cultivars. Postharvest Biol. Technol. 36: 21-30.

Panavas, T., A. Pikula, P.D. Reid, B. Rubinstein and E.L. Walker (1999) Identification of senescence-associated genes from daylily petals Plant Mol. Biol. 40: 237-248.

Park, K.Y., A. Drory and W.R. Woodson (1992) Molecular cloning of an 1-aminocyclopropane-1-carboxylate synthase from senescing carnation flower petals. Plant Mol. Biol. 18: 377-386.

Pennell, R.I. and C.Lamb (1997) Programmed cell death in plants. Plant Cell 9: 1157-1168.

Porat, R., A.Borochov and A.H.Halevy (1994) Pollination-induced changes in ethylene production and sensitivity to ethylene in cut dendrobium orchid flowers. Sci. Hortic. 58: 215-221.

Price,A.M., D.F.A. Orellana, F.M. Salleh, R. Stevens, R.Acock, V. Buchanan-Wollaston, A.D. Stead and H.J.Rogers (2008) A comparison of leaf and petal senescence in wallflower reveals common and distinct patterns of gene expression and physiology. Plant Physiol. 147: 1898-1912.

Primack, R.B. (1985) Longevity of individual flowers. Annu. Rev. Ecol. Syst. 16: 15-37.

Qiao,H., K.N.Chang, J.Yazaki and J.R.Ecker (2009) Interplay between ethylene, ETP1/ETP2 F-box proteins, and degradation of EIN2 triggers ethylene responses in Arabidopsis. Genes Dev. 23: $512-521$.

Qiao,H., Z.X. Shen, S.S.C.Huang, R.J.Schmitz, M.A.Urich, S.P. Briggs and J.R. Ecker (2012) Processing and subcellular trafficking of ER-tethered EIN2 control response to ethylene gas. Science 338: 390-393.

Rogers, H.J. (2006) Programmed cell death in floral organs: how and why do flowers die? Ann. Bot. 97: 309-315.

Rogers, H.J. (2013) From models to ornamentals: how is flower senescence regulated? Plant Mol. Biol. 82: 563-574.

Sakai,H., J.Hua, Q.G.Chen, C.Chang, L.J.Medrano, A.B.Bleecker and E.M. Meyerowitz (1998) ETR2 is an ETR1-like gene involved in ethylene signaling in Arabidopsis. Proc. Natl. Acad. Sci. USA 95: 5812-5817.

Sanikhani,M., H.Mibus, B.M.Stummann and M.Serek (2008) 
Kalanchoe blossfeldiana plants expressing the Arabidopsis etr 1-1 allele show reduced ethylene sensitivity. Plant Cell Rep. 27: 729737.

Savin, K.W., S.C.Baudinette, M.W.Graham, M.Z.Michael, G.D. Nugent, C.Y.Lu, S.F. Chandler and E.C.Cornish (1995) Antisense ACC oxidase RNA delays carnation petal senescence. Hortscience 30: 970-972.

Scariot, V., R. Paradiso, H. Rogers and S. De Pascale (2014) Ethylene control in cut flowers: Classical and innovative approaches. Postharvest Biol. Technol. 97: 83-92.

Serek, M., R.B. Jones and M.S. Reid (1994) Role of ethylene in opening and senescence of Gladiolus sp. flowers. J. Am. Soc. Hortic. Sci. 119: 1014-1019.

Sexton, R., G. Laird and W.G. van Doorn (2000) Lack of ethylene involvement in tulip tepal abscission. Physiol. Plant. 108: 321-329.

Shahri, W. and I. Tahir (2014) Flower senescence: some molecular aspects. Planta 239: 277-297.

Shaw, J.F., H.H.Chen, M.F. Tsai, C.I. Kuo and L.C.Huang (2002) Extended flower longevity of Petunia hybrida plants transformed with boers, a mutated ERS gene of Brassica oleracea. Mol. Breed. 9: 211-216.

Shi, L.S. and J.P.Liu (2016) Molecular cloning and expression analysis of an 1-aminocyclopropane-1-carboxylate synthase gene from Oncidium Gower Ramsey. Biochem. Biophys. Res. Commun. 469: 203-209.

Shibuya, K., M.Nagata, N. Tanikawa, T. Yoshioka, T.Hashiba and S. Satoh (2002) Comparison of mRNA levels of three ethylene receptors in senescing flowers of carnation (Dianthus caryophyllus L.). J. Exp. Bot. 53: 399-406.

Shibuya, K., K.G.Barry, J.A.Ciardi, H.M.Loucas, B.A. Underwood, S. Nourizadeh, J.R.Ecker, H.J.Klee and D.G.Clark (2004) The central role of PhEIN2 in ethylene responses throughout plant development in petunia. Plant Physiol. 136: 2900-2912.

Shibuya, K. and D.G. Clark (2006) Ethylene: current status and future directions of using transgenic techniques to improve flower longevity of ornamental crops. J. Crop. Improv. 18: 391-412.

Shibuya, K. (2012) Molecular mechanisms of petal senescence in ornamental plants. J. Japan. Soc. Hort. Sci. 81: 140-149.

Shibuya, K., K. Shimizu, T. Niki and K. Ichimura (2014) Identification of a NAC transcription factor, EPHEMERAL1, that controls petal senescence in Japanese morning glory. Plant J. 79: 1044-1051.

Shibuya, K. and K. Ichimura (2016) Physiology and molecular biology of flower senescence. In: Pareek, S. (ed.) Postharvest ripening physiology of crops, CRC Press, Boca Raton, pp. 109-138.

Shibuya, K., T. Yamada and K. Ichimura (2016) Morphological changes in senescing petal cells and the regulatory mechanism of petal senescence. J. Exp. Bot. 67: 5909-5918.

Shimizu-Yumoto, H. and K. Ichimura (2006) Involvement of high sensitivity of flag petal to ethylene on its closing in cut sweet pea flowers. J. Japan. Soc. Hort. Sci. 75 (Suppl. 1): 246.

Shimizu-Yumoto, H. and K. Ichimura (2009) Cultivar variation in the vase life of unpollinated Eustoma flowers associated with ethylene. Hort. Res. (Japan) 8: 359-364.

Shimizu-Yumoto, H. and K. Ichimura (2012) Effects of ethylene, pollination, and ethylene inhibitor treatments on flower senescence of gentians. Postharvest Biol. Technol. 63: 111-115.

Shinozaki,Y., T.Tanabata, I. Ogiwara, T.Yamada and M.Kanekatsu (2011) Application of digital image analysis system for fine evaluation of varietal differences and the role of ethylene in visible petal senescence of morning glory. J. Plant Growth Regul. 30: 229-234.

Solano, R., A.Stepanova, Q.Chao and J.R.Ecker (1998) Nuclear events in ethylene signaling: a transcriptional cascade mediated by ETHYLENE-INSENSITIVE3 and ETHYLENE-RESPONSEFACTOR1. Genes Dev. 12: 3703-3714.

Sriskandarajah, S., H.Mibus and M.Serek (2007) Transgenic Campanula carpatica plants with reduced ethylene sensitivity. Plant Cell Rep. 26: 805-813.

Tanase, K. and K. Ichimura (2006) Expression of ethylene receptors $D l-E R S 1-3$ and Dl-ERS2, and ethylene response during flower senescence in Delphinium. J. Plant Physiol. 163: 1159-1166.

Tanase, K., R.Aida, H. Yamaguchi, N. Tanikawa, M.Nagata, T. Onozaki and K. Ichimura (2011) Heterologous expression of a mutated carnation ethylene receptor gene, Dc-ETR1nr, suppresses petal abscission and autocatalytic ethylene production in transgenic Torenia fournieri Lind. J. Japan. Soc. Hort. Sci. 80: 113-120.

Tanase, K., C. Nishitani, H. Hirakawa, S. Isobe, S. Tabata, A. Ohmiya and T.Onozaki (2012) Transcriptome analysis of carnation (Dianthus caryophyllus L.) based on next-generation sequencing technology. BMC Genomics 13: 292.

Tang, X., H.Wang, A.S. Brandt and W.R. Woodson (1993) Organization and structure of the 1-aminocyclopropane-1-carboxylate oxidase gene family from Petunia hybrida. Plant Mol. Biol. 23: $1151-1164$.

Tang, X., A. Gomes, A. Bhatia and W.R. Woodson (1994) Pistil-specific and ethylene-regulated expression of 1-aminocyclopropane-1carboxylate oxidase genes in petunia flowers. Plant Cell 6: 12271239.

van Doorn, W.G. (2001) Categories of petal senescence and abscission: a re-evaluation. Ann. Bot. 87: 447-456.

van Doorn, W.G., P.A. Balk, A.M.van Houwelingen, F.A.Hoeberichts, R.D.Hall, O.Vorst, C.van der Schoot and M.F.van Wordragen (2003) Gene expression during anthesis and senescence in Iris flowers. Plant Mol. Biol. 53: 845-863.

van Doorn, W.G. and E.J. Woltering (2008) Physiology and molecular biology of petal senescence. J. Exp. Bot. 59: 453-480.

Wagstaff, C., T.J.Yang, A.D.Stead, V.Buchanan-Wollaston and J.A. Roberts (2009) A molecular and structural characterization of senescing Arabidopsis siliques and comparison of transcriptional profiles with senescing petals and leaves. Plant J. 57: 690-705.

Waki, K., K. Shibuya, T.Yoshioka, T.Hashiba and S.Satoh (2001) Cloning of a cDNA encoding EIN3-like protein (DC-EIL1) and decrease in its mRNA level during senescence in carnation flower tissues. J. Exp. Bot. 52: 377-379.

Wang,D., J.Fan and R.S.Ranu (2004) Cloning and expression of 1-aminocyclopropane-1-carboxylate synthase cDNA from rosa (Rosa $\times$ hybrida). Plant Cell Rep. 22: 422-429.

Wang, H. and W.R.Woodson (1991) A flower senescence-related mRNA from carnation shares sequence similarity with fruit ripening-related mRNAs involved in ethylene Biosynthesis. Plant Physiol. 96: 1000-1001.

Wang, H., G. Stier, J.Lin, G. Liu, Z.Zhang, Y.H.Chang, M.S. Reid and C.Z.Jiang (2013) Transcriptome changes associated with delayed flower senescence on transgenic petunia by inducing expression of etr 1-1, a mutant ethylene receptor. PLoS ONE 8: e65800.

Wang, T.W. and R.N.Arteca (1995) Identification and characterization of cDNAs encoding ethylene biosynthetic enzymes from Pelargonium $\times$ hortorum cv Snow Mass leaves. Plant Physiol. 109: 627-636.

Wang, Y. and P.P.Kumar (2007) Characterization of two ethylene receptors PhERS1 and PhETR2 from petunia: PhETR2 regulates timing of anther dehiscence. J. Exp. Bot. 58: 533-544.

Wilkinson, J.Q., M.B.Lanahan, D.G.Clark, A.B.Bleecker, C.Chang, 
E.M. Meyerowitz and H.J. Klee (1997) A dominant mutant receptor from Arabidopsis confers ethylene insensitivity in heterologous plants. Nat. Biotechnol. 15: 444-447.

Wilmowicz,E., K. Frankowski, A.Kucko, J.Kesy and J.Kopcewicz (2014) Involvement of the IAA-regulated ACC oxidase gene PnACO3 in Pharbitis nil flower inhibition. Acta Biol. Crac. Ser. Bot. 56: 90-96.

Woltering, E.J. and W.G. van Doorn (1988) Role of ethylene in senescence of petals - morphological and taxonomical relationships. J. Exp. Bot. 39: 1605-1616.

Woltering,E.J., P.A.Balk, M.A.Nijenhuis-de Vries, M.Faivre, G. Ruys, D. Somhorst, S. Philosoph-Hadas and H. Friedman (2005) An auxin-responsive 1-aminocyclopropane-1-carboxylate synthase is responsible for differential ethylene production in gravistimulated Antirrhinum majus L. flower stems. Planta 220: 403-413.

Wu, M.J., L.Zacarias and M.S. Reid (1991) Variation in the senescence of carnation (Dianthus caryophyllus L.) cultivars. II. Comparison of sensitivity to exogenous ethylene and of ethylene binding. Sci. Hortic. 48: 109-116.

Xu, X.J., T. Gookin, C.Z.Jiang and M.Reid (2007) Genes associated with opening and senescence of Mirabilis jalapa flowers. J. Exp. Bot. 58: 2193-2201.

Xue, J.Q., Y.H.Li, H.Tan, F. Yang, N. Ma and J.P. Gao (2008) Expression of ethylene biosynthetic and receptor genes in rose floral tissues during ethylene-enhanced flower opening. J. Exp. Bot. 59:
2161-2169.

Yagi, M., S.Kosugi, H.Hirakawa, A. Ohmiya, K. Tanase, T.Harada, K. Kishimoto, M. Nakayama, K. Ichimura, T. Onozaki et al. (2014) Sequence analysis of the genome of carnation (Dianthus caryophyllus L.). DNA Res. 21: 231-241.

Yamada, T., Y.Takatsu, M.Kasumi, K. Ichimura and W.G. van Doorn (2006) Nuclear fragmentation and DNA degradation during programmed cell death in petals of morning glory (Ipomoea nil). Planta 224: 1279-1290.

Yang, S.F. and N.E. Hoffman (1984) Ethylene biosynthesis and its regulation in higher plants. Annu. Rev. Plant Physiol. 35: 155-189.

Yin, J., X. Chang, T. Kasuga, M. Bui, M.S. Reid and C.Z. Jiang (2015) A basic helix-loop-helix transcription factor, $\mathrm{PhFBH4}$, regulates flower senescence by modulating ethylene biosynthesis pathway in petunia. Hortic. Res. 2: 15059.

Zhou, L., L. Dong, P.Y.Jia, W.R. Wang and L.Y.Wang (2010) Expression of ethylene receptor and transcription factor genes, and ethylene response during flower opening in tree peony (Paeonia suffruticosa). Plant Growth Regul. 62: 171-179.

Zhou, L., C. Zhang, J.X. Fu, M. Liu, Y.H.Zhang, Y.J. Wang and L. Dong (2013) Molecular characterization and expression of ethylene biosynthetic genes during cut flower development in tree peony (Paeonia suffruticosa) in response to ethylene and functional analysis of PSACS1 in Arabidopsis thaliana. J. Plant Growth Regul. 32: $362-375$. 